\title{
Dr. Margaret McCallum-Johnston: Canada's first female anesthesiologist
}

\author{
Amreet Dhaliwal, BSc
}

Received: 16 April 2018/Accepted: 16 April 2018/Published online: 22 May 2018

(c) Canadian Anesthesiologists' Society 2018

Dr. Margaret McCallum-Johnston (1875-1947), a graduate of the Ontario Medical College for Women (OMCW), was a pioneer in the practice of anesthesia in Canada and helped pave the way for many female physicians to follow. A woman of many firsts, Dr. McCallum-Johnston was the first female to be offered a position as resident physician with The Hospital for Sick Children in Toronto in $1900 .^{1}$ After her training and marriage to Dr. Samuel Johnston (who himself is considered the first full time anesthesiologist in Canada), Dr. McCallum-Johnston was a key figure in the founding of the Department of Anesthesia at the Women's College Hospital in Toronto, serving as its inaugural Chief in $1914 .^{2}$ During her 12-year tenure as Chief, the department quickly became one of the most prestigious in Canada. Under her supervision, the anesthetic staff successfully administered anesthesia for a number of operations including Cesarean and forcepsassisted deliveries.

Dr. McCallum-Johnston also worked with, and helped break barriers for, many female colleagues including Dr. Hannah Reid, a fellow graduate of the OMCW. Under Dr. McCallum-Johnston's guidance, Dr. Reid succeeded her in the role of Chief of Anesthesia, becoming the second consecutive woman to lead the department. In addition to her groundbreaking work in the field of anesthesia, Dr. McCallum-Johnston also held positions such as the

\footnotetext{
A. Dhaliwal, BSc ( $\square)$

Rady Faculty of Health Sciences, University of Manitoba,

Winnipeg, MB, Canada

e-mail: dhaliwaa@myumanitoba.ca
}

President of the Toronto Suffrage Association and was the first representative of medical alumni for the National Commission for Women. ${ }^{3}$ As an active member of society and advocate for women's welfare, Dr. Margaret McCallum-Johnston had an outstanding career that opened the doors for many women in years to come.

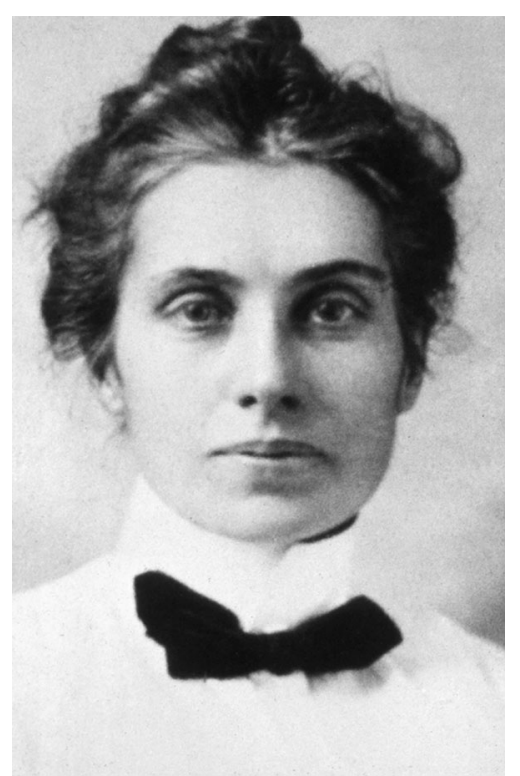

Figure This photo of Dr. Margaret McCallum-Johnston first appeared in the 26th annual report of The Hospital for Sick Children, published in 1901. Reproduced by permission of Hospital Archives, The Hospital for Sick Children, Toronto, ON, Canada 
Acknowledgements Heather Gardiner, archivist at the Miss Margaret Robins Archives of Women's College Hospital in Toronto, and David Wencer, archivist at The Hospital for Sick Children in Toronto, provided much needed information and fact checking for this article.

Conflicts of interest None declared.

Editorial responsibility This submission was handled by Dr. Hilary P. Grocott, Editor-in-Chief, Canadian Journal of Anesthesia.

\section{References}

1. Thompson D, Kronberg J. History of the Department of Anaesthesia Women's College Hospital. Available from URL:
http://www.anesthesia.webservices.utoronto.ca/Assets/Anesthesia Digital Assets/Anesthesia/Anesthesia Digital Assets/history/affwch.pdf (accessed April 2018).

2. Women's College Hospital. About the Department of Anesthesia. Available from URL: http://www.womenscollegehospital.ca/ Education-and-Training/Anesthesia/about-department (accessed April 2018).

3. Giddens $J L$, Whitehead C. Awakened from Sleep: A comparative Essay Highlighting the First Canadian Woman Anesthesiologist Dr. Margaret McCallum Johnston and Present Day Gender Differences Within Canadian Anesthesiology. Available from URL: http://www.royalcollege.ca/portal/page/portal/rc/common/ documents/events/icre/2014proceedings/slides/Health_Policy_and_ Residency_Education/J_Giddens.pdf (accessed April 2018). 